\title{
PENGARUH SPIRITUALITAS KERJA TERHADAP KEPUASAN KERJA DOSEN POLITEKNIK NEGERI MANADO
}

\author{
1)Seska Meily Hermin Mengko, 2)Vesty Like Sambeka \\ 1, 2)Politeknik Negeri Manado \\ 1)seskamengko@gmail.com
}

\begin{abstract}
Abstrak
Penelitian ini bertujuan untuk mengetahui apakah ada pengaruh positif langsung spiritualitas kerja terhadap kepuasan kerja. Penelitian ini dilakukan dengan menggunakan metode kuantitatif. Sampel penelitian ini adalah 174 responden yang dipilih secara acak. Hasil penelitian menyimpulkan: adanya pengaruh positif langsung spiritualitas kerja terhadap kepuasan kerja dosen. Sebagai implikasi dari temuan penelitian ini adalah bahwa meningkatkan kepuasan kerja dan spiritualitas kerja dosen harus dipertimbangkan.

Kata kunci: spiritualitas kerja, kepuasan kerja
\end{abstract}

\section{THE EFFECT OF SPIRITUALITY OF WORK ON LECTURE'S JOB SATISFACTION OF THE MANADO STATE POLYTECHNIC}

\author{
1)Seska Meily Hermin Mengko, 2)Vesty Like Sambeka \\ 1, 2)Politeknik Negeri Manado \\ 1)seskamengko@gmail.com
}

\begin{abstract}
The objective of this research is to study the direct effect of the spirituality of work on job satisfaction of the lecture's the Manado State Polytechnic. The research aimed at examining whether there is a direct positive influence of spirituality of work on job satisfaction. This research was conducted using quantitative methods. The samples of this research were 174 lectures selected randomly. The result of the research concluded: there is a direct positive influence of the spirituality of work toward lecturer's job satisfaction. As the implication of this research finding are that improve lecture's job satisfaction and spirituality of work must be taken into consideration.
\end{abstract}

Keywords: the spirituality of work, job satisfaction 


\section{Pendahuluan}

Dunia modern saat ini terkendala oleh masalah sosial, ekonomi, dan lingkungan yang merupakan hasil dari keserakahan manusia dan kurangnya cinta dan kasih sayang. Hal tersebut adalah masalah skala besar yang telah memicu manusia dalam pencarian baru untuk kehidupan yang harmoni dan perdamaian, pencarian yang pada dasarnya adalah sebuah perjalanan spiritual. Pendekatan spiritual ini mengakui bahwa orang bekerja tidak hanya dengan tangan mereka, tetapi juga dengan hati atau semangat mereka (Ashmos \& Duchon, 2000).

Spiritualitas kerja baru-baru ini muncul sebagai aspek penting dari organisasi dan karenanya, menjadi topik penelitian yang signifikan dalam ilmu organisasi. Sejak akhir 1990-an, publikasi seperti Wall Street Journal, Business Week, Fortune, dan lain-lain telah melaporkan keinginan yang berkembang di antara karyawan untuk makna dan tujuan di tempat kerja.

Spiritualitas di tempat kerja bukanlah ide pinggiran. Bahkan, spiritualitas di tempat kerja membahas aktivitas manusia yang berkaitan dengan pengembangan individu, kasih sayang, kebermaknaan dan sukacita di tempat kerja, kejujuran, kepercayaan, komitmen kerja, kesejahteraan karyawan dan kinerja (Petchsawang \& Duchon, 2012). Organisasi yang sukses seperti HewlettPackard, Tom dari Maine, Ford Motor Company, Bank Duni, AT \& T, Chase Manhattan Bank, DuPont, dan Apple Computer, membuat program yang membawa spiritualitas ke tempat kerja. Di Nigeria, ada kelangkaan studi penelitian untuk aplikasi dan dampak spiritualitas pada karyawan di tempat kerja. Yang sudah ada, Mojoyinola (2010) pada studi tentang peran spiritualitas dalam kesehatan, penyakit dan pengobatan. Sementara Ajala \& Mojoyinola (2013) membahas perlunya integrasi spiritualitas dalam pendidikan pekerjaan sosial, tidak hanya pada spiritualitas dan kesejahteraan karyawan di sektor industri saja.

Fenomena spiritualitas tempat kerja digambarkan sebagai pengalaman hidup batin yang bertumbuh oleh pengalaman yang bermakna (Ashmos \&Duchon, 2000). Karyawan ingin menanamkan hidup mereka dengan makna yang lebih dalam melalui pekerjaan (Hansen \& Keltner, 2012). Karena pada umumnya orang menghabiskan sebagian besar hidup mereka di tempat kerja dan sering mendapatkan identitas sosial mereka dari tempat kerja mereka. Apa yang mereka alami dalam pekerjaan mereka sangat mempengaruhi kesehatan mental dan fisik sehingga keinginan untuk menjadi lebih bermakna dalam hubungan dan rasa tujuan yang lebih besar di tempat kerja menjadi suatu harapan (Belwalkar \& Vohra, 2016).

Giacalone \& Jurkiewicz (2003) mendefinisikan dan melihat 'spiritualitas sebagai kerangka nilai-nilai organisasi yang dibuktikan dalam budaya yang mempromosikan pengalaman transendensi karyawan melalui proses kerja, memfasilitasi rasa terhubung dengan orang lain dengan cara yang memberikan perasaan kelengkapan dan kegembiraan. Dengan kata lain, spiritualitas adalah pencarian identitas batin, keterhubungan dan transendensi (Kinjerski \& Skrypnek, 2004).

Di era sekarang, perguruan tinggi menghadapi banyak rintangan karena tidak adanya spiritualitas di tempat kerja, misalnya: stres, beban kerja tinggi, tidakhadiran, dan politik organisasi. Eksistensi spiritualitas kerja mengacu pada individu dalam pencarian untuk menemukan makna dalam pekerjaan mereka. Kapasitas eksistensial spiritualitas yang ditawarkan oleh Bennis dan Nanus (Sanders, Hopkins, \& Geroy, 2005, p. 46) menyatakan bahwa ini mengacu pada kapasitas perguruan tinggi untuk mempengaruhi dan mengatur kebermaknaan dosen dalam kehidupan yang dapat dikembangkan dengan memiliki pekerjaan yang berarti. Seperti melakukan upaya yang disengaja untuk membantu individu menemukan makna dengan memberikan otonomi, tanggung jawab, signifikansi tugas, identitas, kompleksitas, tantangan, dan keragaman (Hackman \& Oldham, 1975).

Perguruan tinggi yang membangkitkan nilai spiritualitas kerja dosen diduga akan mengalami pertumbuhan dalam pen- 
capaian tujuan. Dosen yang merasa kehadiran dan kapabilitasnya dihargai dan diterima oleh perguruan tinggi akan merasa hidup dalam pekerjaannya sehingga dapat memberi arti bagi keberlangsungan pekerjaannya dan dalam membangun hubungan dengan orang-orang yang berada dilingkungan sekitarnya. Dengan asumsi jika pengembangan spiritualitas kerja memberi nilai positif bagi dosen maka akan meningkatkan kepuasan dosen dalam bekerja.

Berdasarkan uraian yang telah disampaikan tersebut, tujuan penelitian ini adalah untuk megetahui apakah spiritualitas kerja dapat mempengaruhi kepuasan kerja dosen Politeknik Negeri Manado.

\section{Konsep Spiritualitas Kerja}

Ada beberapa penelitian tentang spiritualitas tempat kerja, di mana konsep itu tidak hanya diuji secara empiris tapi juga dioperasikan. Penelitian yang dilakukan oleh Afsar \& Rehman (2015) adalah salah satu studi yang mempelopori pengujian efek kerahasiaan tempat kerja terhadap komitmen organisasi seiring dengan keterlibatan pekerjaan. dalam dimensi seperti rasa masyarakat, penyelarasan nilai, dan makna kerja.

Tujuan spiritualitas di tempat kerja adalah mencapai potensi tertinggi dan memiliki perilaku positif dan interaksi dengan alam semesta. Organisasi yang tujuannya didasarkan pada nilai spiritual memberi lebih banyak kesempatan untuk pertumbuhan dan perkembangan pribadi. Dan rasa pertumbuhan ini akan membantu meningkatkan semangat dan antusiasme karyawan (Neck \& Milliman, 1994).

Spiritualitas kerja adalah sebuah kerangka nilai-nilai organisasi yang ditunjukkan dalam budaya yang meningkatkan pengalaman karyawan tentang pentingnya proses kerja, mempermudah perasaan mereka dihubungkan dengan yang lain sedemikian rupa sehingga memberikan rasa kesempurnaan/sukacita. Mereka melihat spiritualitas di tempat kerja pada tiga tingkatan: (1) tingkat individu sebagai penggabungan nilai-nilai spiritual pribadi dalam lingkungan kerja, (2) tingkat organisasi se- bagai organisasi iklim atau budaya spiritual yang mencerminkan persepsi individu dari nilai-nilai spiritual dalam pengaturan organisasi dan (3) tingkat interaktif sebagai interaksi antara nilai-nilai pribadi seseorang dan nilai-nilai organisasi (Giacalone \& Jurkiewicz dikutip dari Miller \& Ewest, 2013).

Spiritualitas kerja didefinisikan sebagai pengalaman karyawan yang bergairah dan memperoleh energi dari pekerjaan mereka, mendapatkan makna dan tujuan dalam pekerjaan mereka, merasa bahwa mereka dapat mengekspresikan diri mereka di tempat kerja dan merasa ada hubungan dengan orang-orang dengan siapa mereka bekerja (Kinjerski \& Skrypnek, 2004, p. 26). Ivancevich, Kanopaske dan Matteson memberikan definisi tentang spiritualitas kerja yaitu seseorang memiliki kehidupan batin dalam diri mereka yang menumbuhkan dan ditumbuhkan oleh pekerjaan yang bermakna dan pekerjaan yang menantang.

Tiga perspektif yang berbeda diperkenalkan Karakas (2010), bagaimana spiritualitas yang mendukung kinerja organisasi yaitu: (a) spiritualitas meningkatkan kesejahteraan karyawan dan kualitas hidup; (b) spiritualitas menyediakan karyawan rasa tujuan dan makna di tempat kerja; (c) spiritualitas menyediakan karyawan rasa keterkaitan dengan masyarakat.

Spiritualitas kerja didefinisikan sebagai pengalaman karyawan yang bergairah dan memperoleh energi dari pekerjaan mereka, mendapatkan makna dan tujuan dalam pekerjaan mereka, merasa bahwa mereka dapat mengekspresikan diri mereka di tempat kerja dan merasa ada hubungan dengan orang-orang dengan siapa mereka bekerja (Kinjerski \& Skrypnek, 2004).

Spiritulitas di tempat kerja meliputi upaya untuk mencapai tujuan akhir seseorang dalam hidupnya, mengembangkan hubungan yang kuat dengan teman kerja dan orang lain yang terkait dengan pekerjaan, dan memiliki konsistensi atau keselarasan antara kepercayaan seseorang dengan nilai-nilai organisasi mereka (Mitroff dan Denton dalam Marschke, Preziosi, \& Harrington, 2009, p. 4). 
Harrington, Marschke, \& Preziosi (n.d.) mendefinisikan spiritualitas di tempat kerja adalah tentang orang-orang yang memahami diri mereka sendiri sebagai mahkluk yang memiliki semangat dan semangatnya perlu diberi energi melalui pekerjaannya. Ini tentang mengalami tujuan dan makna yang sesungguhnya di tempat kerja lebih dari sekedar cek gaji dan tinjauan tentang kinerja. Spiritualitas adalah menyangkut orang-orang yang berbagi dan mengalami kasih sayang, ketertarikan dan kebersamaan satu dengan yang lain di unit kerja mereka dan organisasi secara keseluruhan.

\section{Konsep Kepuasan Kerja}

Pada dasarnya para ahli memberikan pendapat tentang kepuasan kerja yang keselurahannya merupakan gambaran tentang sikap karyawan terhadap pekerjaannya. Seperti yang dikatakan oleh Colquitt, LePine, \& Wesson (2011, p. 105), kepuasan kerja didefinisikan sebagai keadaan emosional yang menyenangkan yang diakibatkan oleh penilaian terhadap pekerjaan atau pengalaman kerja seseorang.

Parmar (2012, p. 14) mendefinisikan kepuasan kerja adalah pekerjaan yang dilakukan seseorang dengan rasa senang, melakukannya dengan baik dan mendapat penghargaan atas usahanya akan merasa puas dengan pekerjaannya. Kepuasan kerja adalah kunci utama yang mengarah pada pengakuan, pendapatan, promosi dan pencapaian tujuan-tujuan lain yang membawa rasa pemenuhan.

Meskipun analisis teoritis mengkritik kepuasan kerja; konsepnya dianggap terlalu dangkal, namun Luthans (2011, p. 141), terdapat tiga dimensi yang diterima secara umum dalam kepuasan kerja. Pertama, kepuasan kerja merupakan respon emosional terhadap situasi kerja. Dengan demikian, kepuasan kerja dapat dilihat dan dapat diduga. Kedua, kepuasan kerja sering ditentukan menurut seberapa baik hasil yang dicapai memenuhi atau melampaui harapan. Misalnya, jika anggota organisasi merasa bahwa mereka bekerja terlalu keras dari pada yang lain dalam departemen, tetapi menerima penghargaan lebih sedikit maka mereka mungkin akan memiliki sikap negatif terhadap pekerjaan, pimpinan dan/ atau rekan kerja mereka. Mereka tidak puas. Sebaliknya, jika mereka merasa bahwa mereka diperlakukan dengan baik dan dibayar dengan pantas, maka mereka mungkin akan memiliki sikap positif terhadap pekerjaan mereka. Mereka merasa puas. Ketiga, kepuasan kerja mewakili beberapa sikap yang berhubungan.

Dari studi-studi tentang karakteristik pekerjaan, diketahui bahwa sifat dari pekerjaan itu sendiri adalah determinan utama dari kepuasan kerja. Wexley \& Yukl (1988, p. 213) mengidentifikasikan lima dimensi inti dari materi pekerjaan yang meliputi ragam keterampilan (skill variety), identitas pekerjaan (task idetity), kepentingan pekerjaan (task significance) otonomi (autonomy) dan umpan balik (feed back). Setiap dimensi inti dari pekerjaan mencakup aspek besar materi pekerjaan yang dapat mempengaruhi kepuasan kerja seseorang. Hubungannya terletak pada semakin besarnya keragaman aktivitas pekerjaan yang dilakukan sehingga seseorang akan merasa pekerjaannya semakin berarti. Apabila seseorang melakukan pekerjaan yang sama, sederhana dan berulang-ulang, maka akan menyebabkan rasa bosan.

Kepuasan kerja merupakan kumpulan feelings dan believes yang dimiliki orang tentang pekerjaannya. Pengungkapan ketidakpuasan pegawai bisa disampaikan dalam 4 cara: (1) respon voice (aktif \& konstruktif, memberikan saran), (2) response loyalty (pasif: tidak melakukan apapun/ konstruktif: harapan kondisi membaik), (3) respon neglect (pasif : mau tau/destruktif: membiarkan kondisi memburuk), (4) respon exit (destruktif: karyawan keluar/aktif: mencari pekerjaan baru) (Robbins, 2013).

Spiritualitas Tempat Kerja dan Kepuasan Kerja

Giacalone \& Jurkiewicz (2003) telah melakukan studi empiris dan mencatat bahwa spiritualitas kerja memang memiliki pengaruh terhadap sikap rekan sejawat dengan memainkan peran penting. Gupta, 
Kumar, \& Singh (2014) melakukan studi di mana mereka memeriksa pengaruh spiritualitas kerja terhadap produk perusahaan, produk ini mencakup kepuasan kerja. Kepuasan kerja adalah respon yang paling positif dan efektif terhadap pekerjaan yang keluar sebagai hasil perbandingan antara hasil aktual dan yang diinginkan (Cranny, Smith, \& Stone, 1992).

Dimensi spiritualitas kerja penting untuk memenuhi kebutuhan internal para karyawan dan akan sangat membantu dan meyakinkan respon positif dari karyawan. Oleh karena itu, ada dampak yang signifikan antara spiritualitas tempat kerja dan kepuasan kerja (Gupta et al., 2014).

Berarti pekerjaan membawa positif dalam kepuasan kerja. Komunitas di tempat kerja juga berhubungan positif dengan kepuasan kerja. Nilai organisasi akan memberikan hasil yang signifikan mengenai kepuasan kerja (Hassan, Bin Nadeem, \& Akhter, 2016).

Sebagian besar penelitian empiris menekankan interaksi antara spiritualitas tempat kerja dan kepuasan pekerja terhadap pekerjaan. Chawla \& Guda (2010) meneliti karyawan penjualan, untuk mengetahui hubungan antara spiritualitas kerja, kepuasan kerja, dan rentang kepergiannya, menunjukkan bahwa hasilnya benar-benar positif di antara spiritualitas kerja dan kepuasan kerja.

\section{Metode Penelitian}

Penelitian ini adalah jenis penelitian kuantitatif, dengan metode lapangan dan teknik survei. Populasi dalam penelitian ini adalah seluruh dosen yang berada di lingkungan Politeknik Negeri Manado yang berjumlah 308 orang dan disajikan pada Tabel 1.

Teknik pengambilan sampel yang digunakan melalui Simple random sampling (acak sederhana). Dalam simple random sampling, masing-masing anggota mempunyai kemungkinan yang sama untuk dipilih dalam arti sampel bebas dipilih dari setiap elemen yang ada. Besarnya sampel tidak boleh kurang dari 5\% dari populasi yang ada maka untuk memenuhi kriteri tersebut pengukuran sampel diukur berdasarkan rumus Slovin yaitu sebagai berikut.

$$
n=\frac{N}{1+N e^{2}}
$$

Keterangan:

$\mathrm{n} \quad=$ ukuran sampel

$\mathrm{N}=$ Ukuran populasi

$\mathrm{e} \quad=$ persisi yang digunakan

Tabel 1. Jumlah Dosen Politeknik Negeri Manado

\begin{tabular}{llc}
\hline No & \multicolumn{1}{c}{ Jurusan } & $\begin{array}{c}\text { Jumlah } \\
\text { Dosen }\end{array}$ \\
\hline 1. & Teknik Mesin & 37 orang \\
2. & Teknik Elektro & 60 orang \\
3. & Teknik Sipil & 63 orang \\
4. & Akuntasi & 61 orang \\
5. & Administrasi Bisnis & 41 orang \\
6. & Pariwisata & 46 orang \\
& Jumlah & 308 orang \\
\hline
\end{tabular}

Sumber: Bagian Kepegawaian Politeknik

Negeri Manado, Agustus 2017

Jumlah populasi dalam penelitian ini adalah sebanyak 308 orang. Presisi yang diambil sekitar 5\% untuk menjaga representative dari sampel penelitian. Berdasarkan rumus Slovin, jumlah sampel yang diperoleh sebanyak 174 responden dengan perhituungan sebagai berikut.

$$
\begin{aligned}
& n=\frac{308}{1+308(0,05)^{2}} \\
& n=\frac{308}{1,77} \\
& n=174,01 \\
& n=174
\end{aligned}
$$

Untuk mempermudah penyebaran kuesioner maka masing-masing sampel pada setiap jurusan diteliti sebagai berikut:

$$
n_{i}=\frac{N_{i}}{N \times n}
$$

Keterangan:

$\mathrm{n}_{\mathrm{i}}=$ jumlah sampel menurut sekolah

$\mathrm{n}=$ jumlah sampel seluruh

$\mathrm{N}_{\mathrm{i}}=$ jumlah populasi menurut sekolah

$\mathrm{N}=$ jumlah populasi seluruhnya. 
Tabel 2. Ukuran Proporsional Random Rampling

\begin{tabular}{llcc}
\hline No & \multicolumn{1}{c}{ Jurusan } & $\begin{array}{c}\text { Jumlah } \\
\text { Dosen }\end{array}$ & Ukuran sampel \\
& & \\
\hline 1 & Jurusan Mesin & 37 & $37 / 308 \times 174=21$ \\
2 & Jurusan Elektro & 60 & $60 / 308 \times 174=34$ \\
3 & Jurusan Sipil & 63 & $63 / 308 \times 174=36$ \\
4 & Jurusan Akuntansi & 61 & $61 / 308 \times 174=34$ \\
5 & Jurusan Administrasi & 41 & $41 / 308 \times 174=23$ \\
& Bisnis & & \\
6 & Jurusan Pariwisata & 46 & $46 / 308 \times 174=26$ \\
& $\quad$ Jumlah & $\mathbf{3 0 8}$ & $\mathbf{1 7 4}$ \\
\hline
\end{tabular}

Teknik pengumpulan data dalam penelitian ini menggunakan teknik angket dalam bentuk skala Likert. Variabel yang akan diukur dijabarkan menjadi indikator variabel. Indikator tersebut kemudian dijadikan sebagai titik tolak untuk menyusun item-item instrument yang dapat berupa pernyataan atau pertanyaan. Penelitian ini menggunakan statistik sebagai sebagai analisis data. Teknik analisis data dilakukan secara deskriptif dan inferensial.

\section{Hasil dan Pembahasan}

Instrument Kepuasan Kerja yang digunakan dalam penelitian ini terdiri dari 33 butir pertanyaan yang valid. Rentang skor teoretik yaitu antara 33 sampai dengan 165. Sesuai dengan hasil data penelitian diperoleh data terendah 114 dan data tertinggi 165 . Dengan demikian maka rentang skor adalah 51. Data penelitian selanjutnya diperoleh nilai rata-rata sebesar 145,960, modus 165 dan median 145, sedangkan standard deviasi atau simpangan baku sebesar 11,853.

Tabel 3. Deskripsi Variabel Kepuasan

\begin{tabular}{|c|c|c|}
\hline \multirow{3}{*}{$\overline{\mathrm{N}}$} & \multicolumn{2}{|c|}{ Kerja } \\
\hline & Valid & 174 \\
\hline & Missing & 0 \\
\hline Mean & & 145.960 \\
\hline Median & & 145.000 \\
\hline Mode & & 165.000 \\
\hline Std. Deviation & & 11.853 \\
\hline Variance & & 140.498 \\
\hline Range & & 51.000 \\
\hline Minimum & & 114.000 \\
\hline Maximum & & 165.000 \\
\hline
\end{tabular}

Sumber : Data lapangan, diolah dengan SPSS versi 17.0
Dengan menggunakan aturan Sturges, diperoleh jumlah kelas interval yaitu $\mathrm{BK}=$ $1+3.3 \log (174)=8.39$ (dibulatkan 8). Untuk memperoleh banyaknya kelas digunakan perhitungan range (rentangan) / banyaknya kelas (51 / $8=6.38$, dibulatkan 6). Dengan demikian, distribusi frekuensi dapat ditampilkan pada Tabel 4.

Tabel 4. Distribusi Frekuensi Kepuasan Kerja

\begin{tabular}{cccc}
\hline Interval & $\begin{array}{c}\text { Frekuensi } \\
\text { Absolut }\end{array}$ & $\begin{array}{c}\text { Frekuensi } \\
\text { Relatif }(\%)\end{array}$ & $\begin{array}{c}\text { Frekuensi } \\
\text { Kumulatif (\%) }\end{array}$ \\
\hline $114-120$ & 4 & 2.29 & 2.29 \\
$121-127$ & 3 & 1.71 & 4.00 \\
$128-134$ & 23 & 13.14 & 17.14 \\
$135-141$ & 32 & 18.29 & 35.43 \\
$142-148$ & 46 & 26.29 & 61.71 \\
$149-155$ & 23 & 13.71 & 75.43 \\
$156-162$ & 21 & 12.00 & 87.43 \\
$163-165$ & 22 & 12.57 & 100.00 \\
\hline
\end{tabular}

Sumber : data lapangan, diolah (2017)

Berdasarkan data yang ditampilkan tersebut terlihat bahwa frekuensi absolute terbanyak berada pada kelas interval 142 148 sebanyak 46 responden atau sebesar $26,29 \%$, sedangkan frekuensi absolute terkecil berada pada kelas interval 121-127 sebanyak 3 responden (1,71\%). Gambaran mengenai frekuensi data selanjutnya ditampilkan pada histogram Gambar 1.

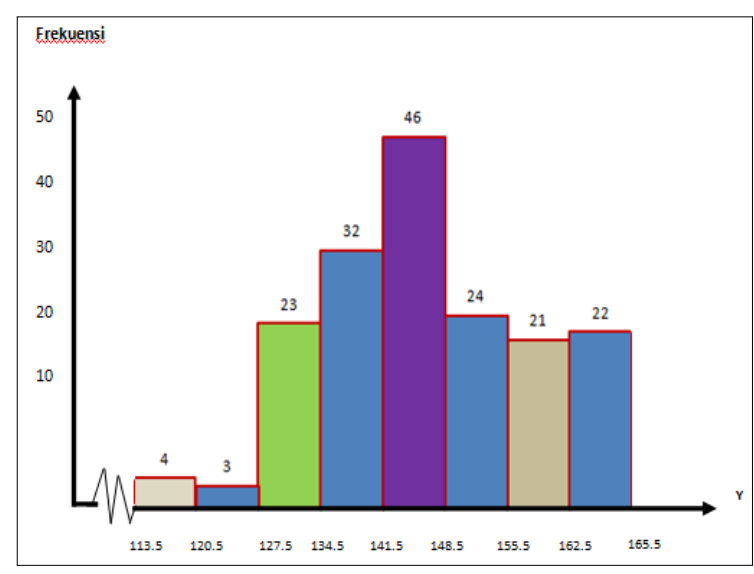

Gambar 1. Histogram Variabel Kepuasan Kerja

Dari Gambar 1 tersebut menunjukkan bahwa nilai skor kepuasan kerja dengan frekuensi atau jumlah responden terbanyak terdapat pada kelas interval kelima yang 
berkisar antara 141,5 sampai dengan 148,5 sebanyak 46 responden atau 26,29\%, sedangkan kedua terbanyak ada di kelas interval ke empat berkisar antara 134,5 sampai dengan 141,5 sebanyak 32 responden atau $18,29 \%$, serta ketiga terbanyak ada dikelas interval ke enam berkisar antara 148,5 sampai dengan 155,5 sebanyak 23 responden atau $13,71 \%$. Jika ketiga kelas tersebut dijumlah diperoleh angka 102 responden atau 58,6\% yang berarti bahwa lebih dari separuh responden setuju dan mendekati setuju terhadap variabel kepuasan kerja.

\section{Spiritualitas Kerja $\left(X_{3}\right)$}

Spiritualitas kerja adalah keadaan dimana seseorang merasa melakukan pekerjaannya dengan cara-cara yang bermakna dalam suatu komunitas untuk mencapai tujuan. Total item valid adalah sebanyak 28 item yang digunakan. Dengan demikian, diperoleh skor teoritis maksimal sebesar 5 x $27=140$ dan skor teoritis terendah $1 \times 28$ $=28$.

Tabel 5. Deskripsi Variabel Spiritualitas

\begin{tabular}{lr}
\multicolumn{2}{c}{ Kerja } \\
\hline $\mathrm{N} \quad r \quad$ Valid & \multicolumn{1}{c}{0} \\
\cline { 2 - 2 } Mean & Missing \\
Median & 122.211 \\
Mode & 120.000 \\
Std. Deviation & 112.00 \\
Variance & 10.501 \\
Range & 110.271 \\
Minimum & 40.00 \\
Maximum & 100.00 \\
\hline
\end{tabular}

Sumber : Data lapangan, diolah (2017)

Variabel spiritualitas kerja memiliki nilai rata-rata (mean) sebesar 122.211 dan berbeda sedikit dengan nilai tengah (median) yaitu sebesar 120 serta modus yaitu 112. Sedangkan standard deviasi sebesar 10.50 menunjukan penyimpangan disekitar rata-rata dengan nilai terbesar 140 dan nilai terkecil 100. Skor variabel spiritualitas kerja memiliki rentang nilai sebesar 40 yang merupakan nilai selisih antara skor tertinggi dengan skor terendah.
Banyaknya kelas dihitung dengan formula Sturgess yaitu BK $=1+3.3$ Log $(174)=8.39$ (dibulatkan 8). Untuk memperoleh banyaknya kelas digunakan perhitungan range (rentangan)/ banyaknya kelas $(40 / 8=5)$. Dengan demikian, distribusi frekuensi dapat ditampilan sebagai berikut:

Tabel 6. Distribusi Frekuensi Variabel $X_{3}$

\begin{tabular}{cccc}
\hline Interval & $\begin{array}{c}\text { Frekuensi } \\
\text { Absolut }\end{array}$ & $\begin{array}{c}\text { Frekuensi } \\
\text { Relatif }(\%)\end{array}$ & $\begin{array}{c}\text { Frekuensi } \\
\text { Kumulatif (\%) }\end{array}$ \\
\hline $100-104$ & 3 & 3.53 & 3.53 \\
$105-109$ & 7 & 8.24 & 11.76 \\
$110-114$ & 41 & 49.41 & 61.18 \\
$115-119$ & 32 & 37.65 & 98.82 \\
$120-124$ & 24 & 28.24 & 127.06 \\
$125-129$ & 17 & 20.00 & 147.06 \\
$130-134$ & 20 & 23.53 & 170.59 \\
$135-140$ & 30 & 35.29 & 205.88 \\
\hline
\end{tabular}

Sumber : Data lapangan, diolah (2017)

Berdasarkan data yang ditampilkan tersebut terlihat bahwa frekuensi absolute terbanyak berada pada kelas interval 110 114 sebanyak 41 responden atau sebesar $49,41 \%$, sedangkan frekuensi absolute terkecil berada pada kelas interval 100-104 sebanyak 3 responden (3,53\%). Gambaran mengenai frekuensi data selanjutnya ditampilkan pada histogram Gambar 2.

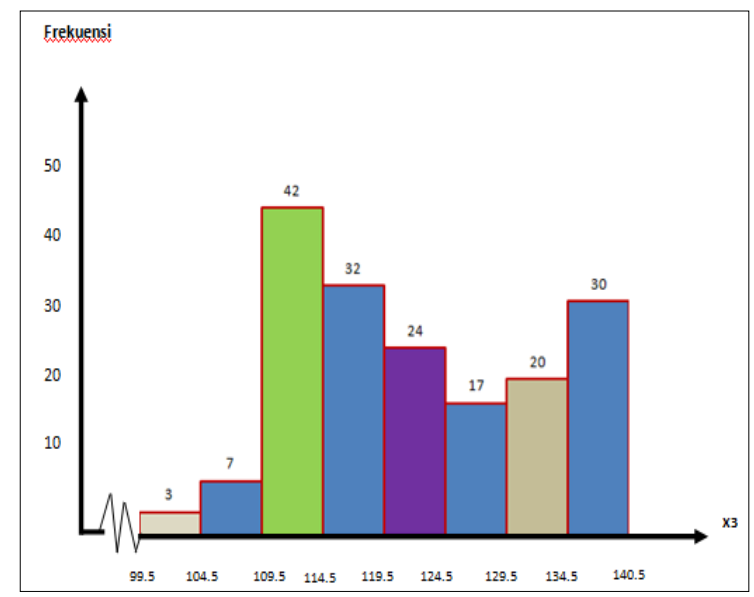

Gambar 2. Histogram Variabel Spiritualitas Kerja

Dari gambar 4.4. histogram tersebut menunjukkan bahwa nilai skor spritualitas kerja dengan frekuensi atau jumlah responden terbanyak terdapat pada kelas interval ketiga yang berkisar antara 109,5 sampai dengan 114,5 sebanyak 41 responden atau 
$28,57 \%$, sedangkan kedua terbanyak ada di kelas interval ke empat berkisar antara 114,5 sampai dengan 119,5 sebanyak 32 responden atau $18,39 \%$, serta ketiga terbanyak ada di kelas interval ke delapan berkisar antara 134,5 sampai dengan 134,5 sebanyak 30 responden atau 17,24\%. Jika ketiga kelas tersebut dijumlah diperoleh angka 104 responden atau 59,7\% yang berarti bahwa lebih dari separuh responden setuju dan mendekati setuju terhadap variabel spiritualitas kerja.

Uji Persyaratan Analisis

Pengujian persyaratan analisis meliputi uji normalitas, linieritas dan signifikansi regresi yang secara rinci diuraikan sebagai berikut :

Signifikansi dan Linearitas Kepuasan Kerja (Y) atas Spiritualitas Kerja (X)

Setelah dilakukan perhitungan uji signifikansi dan linearitas kepuasan kerja $(\mathrm{Y})$ atas spiritualitas kerja $(\mathrm{X})$ menghasilkan persamaan regresi $Y=73,987+0,598 X_{3}$. Hasil analisis varians (ANAVA) model ini terdapat pada Tabel 7.

Dari hasil perhitungan diperoleh $F_{\text {hitung }}$ model regresi sebesar 61,937. Sedangkan pada taraf nyata $\alpha=0.05$ diperoleh $F_{\text {tabel }}$ 1.520. Karena $F_{\text {hitung }}=61,937>$ 1,520. maka koefisien regresinya signifikan.

Selanjutnya pada uji linieritas, hasil perhitungan memperoleh $F_{\text {hitung }}$ sebesar 1,106 . Sedangkan pada taraf nyata $\alpha=0,01$ diperoleh untuk $F_{\text {tabel }}=1,802$. Karena $F_{\text {hitung }}$ $=1,106<F_{\text {tabel }} 1,802$. Maka regresi $Y$ atas $X_{3}$ berbentuk linear.

Pengujian Model

Sebelum dilakukan perhitungan guna menguji model kausalitas dengan menggunakan metode analisis jalur, maka diperlukan data hasil peneltian yang telah diuji dan memenuhi seluruh persyaratan.

Salah satu persyaratan penting dan harus dipenuhi adalah adanya korelasi yang signifikan antara variabel-variabel terkait. Korelasi antar variabel tersebut dihitung dengan menggunakan koefisen korelasi. Dengan menggunakan SPSS 17, diperoleh nilai korelasi antarvariabel sebagai berikut:

Model Struktural dan Matriks Korelasi antar Variabel

Model struktural dalam penelitian ini disajikan ulang seperti yang nampak pada Gambar 3.

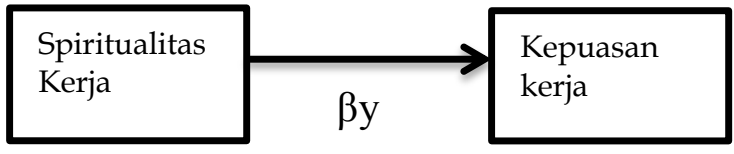

Gambar 3. Hubungan Kausal; X terhadap Y

Dari diagram jalur tersebut diatas, diperoleh satu buah koefisien jalur, yaitu $p_{y}$ Sedangkan hasl perhitungan koefisien korelasi yang diperoleh dengan menggunakan SPSS 17.

Tabel 7. Anova untuk Uji Signifikansi dan Linearitas $Y=73,987+0,598 X_{3}$

\begin{tabular}{lcccccc}
\hline \multicolumn{1}{c}{ Sumber } & \multirow{2}{*}{ Dk } & \multirow{2}{*}{ JK } & \multirow{2}{*}{ RJK } & \multirow{2}{*}{$F_{\text {hitung }}$} & & \multicolumn{2}{c}{$\mathrm{F}_{\text {Tabel }}$} \\
\cline { 6 - 7 } Total & 174 & $24,382,994$ & $24,382,994$ & & & $\mathrm{a}=1 \%$ \\
Koefisien (a) & 1 & 73,987 & 73,987 & & & \\
Regresi (b |a) & 1 & $6,561,359$ & $6,561,359$ & 61,937 & 1,520 & 1,802 \\
Residu & 172 & 17821,635 & 103,614 & & & \\
Tuna Cocok & 33 & $3,096,440$ & 103,03 & 1,106 & 1,520 & 1,802 \\
Galat & 139 & $14,725,195$ & 93,09 & & & \\
\hline
\end{tabular}

$\mathrm{Dk}=$ derajat kebebasan

$\mathrm{JK} \quad=$ Jumlah Kuadrat

RJK = Rerata jumlah kuadrat

$* * \quad=$ Regresi sangat signifikan $\left(\mathrm{F}_{\text {hitung }}=61,937>\mathrm{F}_{\text {tabel }}(\mathrm{\alpha}=0,01=1,520)\right.$

ns $=$ non signifikan $\left(F_{\text {hitung }}=1,106<\mathrm{F}_{\text {tabel }}(\alpha=0,01=1,802)\right.$ 
Selanjutnya dengan menggunakan perhitungan lebih lanjut sesuai dengan langkah-langkah dalam analisis jalur, nilai koefisien jalur tersebut dihitung dan diuji keberartiannya dengan menggunakan statistik $t$, dan apabila jalur yang diuji tersebut mengunjukkan nilai koefisien yang tidak berarti atau tidak signifikan maka jalur tersebut dihilangkan dan kemudian koefisien jalurnya dihitung lagi tanpa menyertakan yang sudah dihilangkan tersebut.

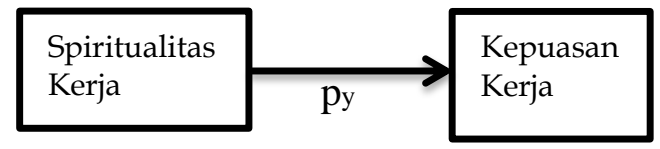

Gambar 4. Hubungan Kausal

Hasil pengolahan data, dengan menggunakan SPSS 17, ditampilkan pada tabel 4,19 dibawah ini dengan rangkuman hasil perhitungan dan pengujian koefisien jalur. uji keseluruhan atau uji $\mathrm{F}$ pada sub-struktur 1, dengan nilai $F_{\text {hitung }}=34,662$ lebih besar daripada $F_{\text {tabel }}$ untuk $\alpha=0,05$ sebesar 2,656, maka dapat dilanjutkan dengan uji individu atau uji t.

Tabel 8. Signifikansi Model Kepuasan

\begin{tabular}{lccccc}
\multicolumn{5}{c}{ Kerja } \\
\hline Model & Sum of & \multicolumn{4}{c}{ Mean } \\
& Squares & Df & Square & F & Sig. \\
\hline 1 Regression & 9254,064 & 3 & 3084, & 34, & $.000^{a}$ \\
& & & 688 & 662 & \\
Residual & 15128,930 & 170 & 88,994 & & \\
Total & 24382,994 & 173 & & \\
a. Predictors: (Constant), spiritualitas kerja, \\
b. Dependent Variable: kepuasan kerja \\
\hline
\end{tabular}

Melalui tabel koefisien diketahui bahwa seluruh jalur hubungan signifikan dengan memperhatikan nilai $t_{\text {hitung }}>1,98$ dan sig $<0,005$. Berdasarkan nilai koefisien beta, spiritualitas kerja memiliki pengaruh dengan koefisien beta sebesar 0,298.
Tabel 9. Koefisien Model Kepuasan Kerja

\begin{tabular}{|c|c|c|c|c|c|}
\hline \multirow[b]{2}{*}{ Model } & $\begin{array}{r}\text { Unstanc } \\
\text { Coeff }\end{array}$ & Unstandardized Standardized & $\begin{array}{c}\text { Standardized } \\
\text { Coefficients }\end{array}$ & \multirow[b]{2}{*}{$\mathrm{T}$} & \multirow[b]{2}{*}{ Sig. } \\
\hline & B & $\begin{array}{l}\text { Std. } \\
\text { Error }\end{array}$ & Beta & & \\
\hline $1 \overline{\text { (Constant) }}$ & 51,062 & 9,584 & & 5,328 & , 000 \\
\hline $\begin{array}{l}\text { spiritualitas } \\
\text { kerja }\end{array}$ & 223 & ,098 & 196 & 2,279 & ,024 \\
\hline
\end{tabular}

Nilai R Square adalah sebesar 0,380 yang mengindikasikan variasi perubahan kepuasan kerja berdasarkan variasi tiga variabel yaitu kepemimpinan yang melayani, efikasi diri, dan spiritualitas kerja. Sinergi antara tiga variabel bebas tersebut mampu mempengaruhi kepuasan kerja sebesar $38,00 \%$, sedangkan sisanya $62.00 \%$ dipengaruhi faktor lain di luar model.

Tabel 10. Rangkuman Perhitungan dan Pengujian Koefisien Struktur 1

\begin{tabular}{ccccc}
\hline Jalur & $\begin{array}{c}\text { Koefisien } \\
\text { Jalur }\end{array}$ & thitung $_{\text {haluel }}$ & $\begin{array}{c}\mathrm{t}_{\text {tabel }} \\
(\alpha=0,05\end{array}$ & Keterangan \\
\hline $\mathrm{p}_{\mathrm{y}}$ & 196 & 2,279 & 1,98 & Signifikan \\
\hline
\end{tabular}

$\underset{\substack{\text { Spiritualitas } \\ \text { Kerja X }}}{\longrightarrow \text { py2 }=0,196} \longrightarrow \begin{gathered}\text { Kepuasan } \\ \text { Kerja Y }\end{gathered}$

Pengujian Hipotesis

Setelah dilakukan pengujian model, kemudian dilakukan pengujian hipotesis untuk mengetahui pengaruh langsung dan tidak langsung antar variabel. Hipotesis yang diajukan akan disimpulkan melalui perhitungan nilai nilai koefisien jalur dan signifikansi. Hasil keputusan terhadap seluruh hipotesis yang diajukan, dijelaskan sebagai berikut:

Pengujian hipotesis untuk membuktikan bahwa spiritualitas kerja (X) berpengaruh langsung terhadap kepuasan kerja (Y). Hipotesis yang diuji sebagai berikut:

$\mathrm{H} 0: \beta \mathrm{y} \leq 0$

$\mathrm{H} 1: \beta y>0$

Tabel 11. Summary Kepuasan Kerja

\begin{tabular}{|c|c|c|c|c|c|c|c|c|c|}
\hline \multirow[b]{2}{*}{ Model } & \multirow[b]{2}{*}{$\mathrm{R}$} & \multirow[b]{2}{*}{ R Square } & \multirow{2}{*}{$\begin{array}{l}\text { Adjusted } \\
\text { R Square }\end{array}$} & \multirow{2}{*}{$\begin{array}{l}\text { Std. Error of } \\
\text { the Estimate }\end{array}$} & \multicolumn{5}{|c|}{ Change Statistics } \\
\hline & & & & & $\begin{array}{l}\text { R Square } \\
\text { Change }\end{array}$ & $\begin{array}{c}F \\
\text { Change }\end{array}$ & df1 & df2 & $\begin{array}{l}\text { Sig. F } \\
\text { Change }\end{array}$ \\
\hline 1 & ,616a & ,380 & ,369 & 9,434 & 380 & 34,662 & 3 & 170 & ,000 \\
\hline
\end{tabular}


Dari hasil perhitungan, nilai koefisien jalur (py) sebesar 0,196 dengan thitung $=$ 2,041 pada $\square=0,05$ diperoleh ttabel $=1,98$. Karena nilai thitung $>$ ttabel, $\mathrm{H} 0$ ditolak $\mathrm{H} 1$ diterima, maka koefisien jalur signifikan. Dari temuan ini dapat ditafsirkan bahwa spiritualitas kerja $(X)$ berpengaruh langsung positif terhadap kepuasan kerja $(\mathrm{Y})$.

\section{Pembahasan}

Subbab ini akan memberikan pembahasan mengenai hasil temuan penelitian yang sudah diuraikan di Bab sebelumnya. Pembahasan mengenai hasil pembuktian hipotesis berdasarkan temuan di lapangan.

Hasil pengujian hipotesis menemukan bahwa spiritualitas kerja berpengaruh positif terhadap kepuasan kerja. Pengaruh positif ini menunjukkan bahwa spiritualitas kerja yang tinggi memberikan implikasi terhadap kepuasan kerja.

Temuan ini mendukung pendapat Kinjerski \& Skrypnek (2004) yang mendefinisikan spiritualitas kerja sebagai pengalaman karyawan yang bergairah dan memperoleh energi dari pekerjaan mereka, mendapatkan makna dan tujuan dalam pekerjaan mereka, merasa bahwa mereka dapat mengekspresikan diri mereka di tempat kerja dan merasa ada hubungan dengan orang-orang yang bekerja dengan mereka. Definisi ini menggambarkan tentang perilaku orang-orang yang merasa puas dalam pekerjaan mereka.

Seseorang yang memiliki spiritualitas kerja memaknai setiap pekerjaan mereka dengan menumbuhkan nilai-nilai diri yang dimilikinya dalam pekerjaan yang bermakna untuk mencapai tujuan, yaitu dengan memelihara sikap welas asih, memiliki kepedulian terhadap sesama, membangun hubungan yang harmonis dengan atasan dan rekan kerja, bersikap jujur pada diri sendiri dan mengatakan yang sebenarnya pada orang lain, dan mengintegrasikan tujuan pribadi dengan tujuan organisasi. Apabila hal itu dilakukan dalam pekerjaan akan menimbulkan kepuasan kerja

Hasil temuan ini juga mendukung pendapat Karakas (2010) berdasarkan tiga perspektif spiritualitas yaitu: (a) spiritua- litas meningkatkan kesejahteraan karyawan dan kualitas hidup, (b) spiritualitas menyediakan karyawan rasa tujuan dan makna di tempat kerja, dan (c) spiritualitas menyediakan karyawan rasa keterkaitan dan masyarakat. Bila dikaji lebih lanjut ketiga poit tersebut merupakan bagian dari faktor-faktor yang dapat memberi pengaruh terhadap kepuasan kerja seperti yang diutarakan oleh Luthans (2011) yaitu: pekerjaan itu sendiri, gaji, kesempatan promosi, pengawasan dan rekan kerja. Karyawan yang merasa puas dengan pekerjaannya adalah karyawan yang merasa sejahtera, merasa bermakna ditempat kerja, dan merasa diterima sebagai bagian dari suatu komunitas masyarakat.

Hasil penilitian ini mendukung penelitian sebelumnya yang dilakukan oleh Eleanor Marschke, Strayer University Dr. Robert Preziosi, Nova Southeastern University, dan Dr. William Harrington, Nova Southeastern University dengan judul Business Executives and Professionals Identify Relationship Between Spirituality at Work and Job Satisfaction. Semua bukti yang dikumpulkan dari penelitian ini menunjukkan hubungan yang kuat dan signifikan antara variabel yaitu terdapat hubungan positif antara spiritualitas di tempat kerja dan kepuasan kerja. Hasil penelitian ini dapat mengubah individu dan organisasi untuk hidup dengan cara yang tidak dibatasi oleh hukum alam.

Penelitian ini juga mendukung penelitian yang dilakukan oleh Leo Agung Manggala Yogatama, Fakultas Psikologi Universitas Atma Jaya Jakarta dan Nilam Widyarini2

Fakultas Psikologi Universitas Gunadarma Jakarta denga judu "Kajian Spiritualitas di Tempat Kerja pada Konteks Organisasi Bisnis" menunjukkan hasil bahwa ada dua faktor yang membentuk iklim spiritual di tempat kerja, yaitu Visi dan Misi yang membuat seseorang termotivasi dan merasakan tujuan di tempat kerja, dan faktor kedua adalah kepedulian mendalam akan kehidupan karyawan.

Hasil penelitian ini mendukung pendapat Mitroff \& Denton (n.d.) Mitroff dan 
Denton yang memberikan pedoman yang dapat digunakan untuk lebih menjelaskan konsep ini.

Pertama, spiritualitas adalah kreativitas Kreativitas meliputi penggunaan warna, tawa dan kebebasan untuk meningkatkan produktivitas. Kreativitas adalah menyenangkan. Ketika orang menikmati apa yang mereka lakukan, mereka bekerja lebih keras. Kreativitas meliputi upaya sadar untuk melihat hal-hal yang berbeda untuk keluar dari kebiasaan dan keyakinan untuk menemukan cara-cara baru dalam berpikir. Kreativitas adalah aspek alami manusia yang sehat.

Kedua, spiritualitas adalah komunikasi ini adalah kendaraan yang memungkinkan orang untuk bekerja sama. Dalam masyarakat, proses pembelajaran didasarkan pada belajar untuk berkomunikasi dengan orang lain. Sebagian besar dari kita belum belajar bagaimana untuk berkomunikasi dengan rekan-rekan untuk tujuan mencapai sesuatu yang bermanfaat bagi orang banyak.

Ketiga, spiritualitas adalah respek. Menghormati diri dan orang lain, meliputi: penghargaan terhadap lingkungan hidup, privasi pribadi orang lain, ruang dan barang-barang fisik mereka, sudut pandang yang berbeda, filosofi, agama, jenis kelamin, gaya hidup, asal etnis, kemampuan fisik, keyakinan dan kepribadian. Ketika kita belajar menghormati rekan-rekan kita, kita bisa belajar untuk menerima perbedaan mereka.

Kempat, spiritualitas adalah partnership. Kemitraan meliputi tanggung jawab individu dan kepercayaan bahwa orang lain akan melakukan sesuai dengan komitmen mereka demi kebaikan team dan mitra. Kemitraan menerima bahwa orang yang berbeda memiliki sudut pandang dan keyakinan yang berbeda, perbedaan digunakan sebagai aspek positif untuk memperluas pengalaman team. Kemitraan mendorong secara seimbang dan adil dan bekerja sama, serta perbedaan pendapat, jujur tanpa permusuhan atau peperangan. Kemitraan mendorong aspek wanita dan pria untuk bekerja bersama-sama, tanpa salah satu yang lebih berkuasa atau mendominasi yang lain. Kurangnya kemitraan menyebabkan isolasi dan persaingan tidak sehat.

Kelima, spiritualitas adalah energi. Kekuatan energi yang sangat positif yang dilepaskan ketika orang merasa kreatif memiliki kebebasan untuk mengekspresikan pendapat mereka dan merasakan rasa hormat dari manajemen mereka dan rekanrekan mereka. Kekuatan energi yang berlawanan menciptakan situasi tempat kerja bermusuhan-termasuk: kekerasan, diskriminasi, tidak menghormati, dan kehilangan produktivitas.

Keenam, spiritualitas adalah Flexibility Fleksibilitas mencakup kemampuan untuk beradaptasi dengan perubahan situasi dan memungkinkan kepercayaan dan kebiasaan sendiri untuk mengubah sesuai kebutuhan. Sebagai dunia kita berubah dengan kecepatan yang selalu cepat, kita perlu mencari cara untuk beradaptasi dan mengubah diri kita dengan itu. Belajar untuk melihat trend dan mempersiapkan mereka adalah salah satu cara fleksibilitas pembelajaran lain adalah untuk belajar tentang kekuatan kita sendiri, kelemahan kita dan kemudian bekerja untuk beroperasi dari kekuatan kita, membiarkan orang lain untuk membantu kita dengan kelemahan kita.

Ketujuh, spiritualitas adalah Fun. Orang-orang yang menikmati pekerjaan hidup mereka bekerja lebih keras, membuat lebih banyak uang, lebih percaya diri, memiliki lebih banyak teman dan jauh lebih sehat daripada orang-orang yang khawatir terus-menerus, bertarung dengan orang lain, merasa takut sepanjang waktu dan merasa rendah diri.

Kedelapan, spiritualitas menemukan diri anda Belajar tentang siapa Anda. Bagaimana Anda dapat mengontrol dunia dengan mengubah sikap Anda dan belajar untuk menghormati dan menerima orang lain membantu menyatukan visi bersamasama, memperkuat energi universal. Di tempat kerja atau dalam kehidupan pribadi kita, sikap kita tentang dunia mendefinisikan bagaimana hidup kita terungkap. 
Selanjutnya Robbins (2013) mengemukakan ciri-ciri organisasi spiritual yaitu:

Pertama, organisasi spritual sangat Memperhatikan Tujuan. Organisasi spiritual membangun budaya mereka berdasarkan tujuan yang bermanfaat. Walaupun mungkin penting, laba bukan merupakan nilai utama organisasi.

Kedua, fokus pada pengembangan individu. Organisasi-organisasi spiritual mengaku bobot dan nilai orang. mereka tidak hanya memberikan jabatan, mereka berusaha menciptakan budaya yang memungkinkan karyawan dapat terus menerus belajar dan bertumbuh. Dengan mengakui pentingnya orang, mereka juga memberikan keamanan kerja.

Ketiga, kepercayaan dan keterbukaan. Ciri-ciri organisasi spiritual adalah kepercayaan timbal-balik, kejujuran dan keterbukaan. Para manajer tidak takut mengakui kesalahan dan mereka cenderung sangat sangat berterus terang dengan karyawan.

Keempat, pemberdayaan karyawan Iklim kepercayaan-tinggi dalam organisasi spiritual, bila digabungkan dengan keinginan memajukan pembelajaran dan pertumbuhan karyawan, mengakibatkan manajemen memberdayakan karyawan mereka sehingga mampu mengambil sebagian besar keputusan yang berhubungan dengan kerja. Para manajer percaya karyawan mampu mengambil keputusan dengan hatihati dan penuh pertimbangan.

Kelima, toleransi terhadap exspresi karyawan. Karakter terakhir yang mem-bedakan organisasi berbasis spiritual adalah bahwa mereka tidak melumpuhkan emosi karyawan. Mereka memungkinkan orang untuk menjadi diri mereka sendiri, mengekspresikan suasana hati dan perasaan mereka tanpa rasa salah dan takut ditegur.

Berdasarkan hasil pengukuran dimensi spiritualitas kerja ditemukan bahwa dimensi tertinggi adalah integritas. Hal ini membuktikan bahwa sikap kerja yang dominan yang ditunjukkan oleh dosen Politeknik Negeri manado adalah dengan integritas dalam bekerja. Intergritas merupakan sikap yang dapat memberi nilai kepercayaan terhadap seseorang karena dengan intergritas seseorang dapat dipercaya dalam segala apa yang ditugaskan.

Fakta empiris menunjukkan bahwa spiritualitas kerja dosen Politeknik Negeri Manado dilihat dari berpikir positif terhadap pekerjaan, Berempati terhadap masalah yang dialami rekan kerja, menemukan semangat di tempat kerja, dipercaya oleh pimpinan dan rekan kerja, melakukan pekerjaan dengan kebenaran, melakukan pekerjaan dengan tanggung jawab penuh, berkontribusi dalam kemajuan institusi, memiliki tujuan dalam bekerja, menanamkan nilai-nilai kebersamaan dalam bekerja.

Walaupun nilai yang diperoleh dalam koefisien jalur tidak cukup tinggi terhadap pengaruh langsung positif pada kepuasan kerja dosen, tetapi sudah dapat menunjukkan bahwa spiritualitas kerja berpengaruh langsung positif terhadap kepuasan kerja dosen Politeknik Negeri Manado.

Berdasarkan fakta empiris di atas, dari hasil analisis menunjukkan bahwa spiritualitas kerja merupakan faktor yang dapat mempengaruhi kepuasan kerja. Dengan demikian, upaya untuk meningkatkan kepuasan kerja dosen dapat dilakukan dengan integritas, menumbuhkan inner life dosen, melakukan pekerjaan dengan caracara yang berarti dan membangun hubungan dengan masyarakat.

\section{Simpulan}

Berdasarkan hasil analisis terhadap variabel-variabel kepuasan kerja dan spiritualitas kerja, dapat disimpulkan bahwa spiritualitas kerja berpengaruh langsung positif terhadap kepuasan kerja dosen Politeknik Negeri Manado. Artinya, perubahan peningkatan spiritualitas kerja akan menyebabkan peningkatan kepuasan kerja dosen Politeknik Negeri Manado.

Berdasarkan simpulan di atas maka implikasi atas hasil penelitian ini adalah Penelitian ini menemukan bahwa terdapat pengaruh langsung positif spiritualitas kerja terhadap kepuasan kerja. Implikasinya jika spiritualitas kerja diperbaiki maka mengakibatkan peningkatan kepuasan kerja dosen. Apabila dosen mengintegrasikan nilai-nilai dirinya dengan nilai-nilai orga- 
nisasi, memiliki integritas dan melakukannya dengan cara-cara yang berarti serta dapat membangun hubungan yang baik dengan pemimpin dan rekan kerja maka dosen akan membentuk sikap positif terhadap dirinya dan pekerjaannya sebagai seorang dosen sehingga menimbulkan apresiasi dirinya terhadap peningkatan pekerjaan.

Berdasarkan kesimpulan dan implikasi di atas, disarankan hal-hal sebagai berikut. Pertama, Politeknik Negeri Manado perlu menyediakan spiritualitas kerja untuk dosen berupa tanggung jawab dan kepercayaan dalam bidang tugas dengan melibatkan dosen dalam berbagai kegiatan agar dosen merasa bernilai dan memiliki makna dalam pekerjaannya.

Kedua, perlunya mempertimbangkan spiritualitas kerja dosen Politeknik Negeri Manado dalam membangun hubungan yang baik sehingga dosen dapat mengintegrasikan nilai-nilai dirinya dengan nilainilai organisasi untuk mencapai tujuan bersama. Ketiga, penelitian ini dapat menjadi bahan masukan dalam pengambilan keputusan untuk pengembangan penelitian-penelitian di perguruan tinggi. Keempat, sebaiknya dilakukan penelitian lanjutan untuk pengkajian secara komprehensif terhadap kepuasan kerja karena kepuasan kerja tidak hanya ditentukan oleh faktor kepemimpinan yang melayani, efikasi diri dan spiritualitas kerja melainkan ditentukannya juga oleh faktor-faktor lain yang perlu dikaji lebih jauh.

\section{Daftar Pustaka}

Afsar, B., \& Rehman, M. (2015). The relationship between workplace spirituality and innovative work behavior: the mediating role of perceived person-organization fit. Journal of Management, Spirituality $\mathcal{E}$ Religion, 12(4), 329-353.

https:// doi.org/10.1080/14766086.201 5.1060515

Ajala, E. M., \& Mojoyinola, J. K. (2013). Spirituality in health care and industrial welfare: needs for its integration in social work education.
In The 8th North American Spirituality and Social Work Conference. Puerto Rico: University of Puerto Rico, Rio Piedras Campus.

Ashmos, D. P., \& Duchon, D. (2000). Spirituality at work: A conceptualization and measure. Journal of Management Inquiry, 9(2), 134-145.

https:// doi.org/10.1177/10564926009 2008

Belwalkar, S., \& Vohra, V. (2016). Workplace spirituality, job satisfaction and organizational citizenship behaviors: a theoretical model. International Journal of Business and Management, 11(8), 256. https:// doi.org/10.5539/ijbm.v11n8p 256

Chawla, V., \& Guda, S. (2010). Individual spirituality at work and its relationship with job satisfaction, propensity to leave and job commitment. Journal of Human Values, 16(2), 157-167.

https://doi.org/10.1177/09716858100 1600203

Colquitt, J. A., LePine, J. A., \& Wesson, M. J. (2011). Organizational behavior, improving performance and commitment in the workplace. New York: McGrawHill.

Cranny, C. J., Smith, P. C., \& Stone, E. F. (1992). Job satisfaction: How people feel about their jobs and how it affects their performance. New York: Lexington Books.

Giacalone, R. A., \& Jurkiewicz, C. L. (2003). Right from wrong: the influence of spirituality on perceptions of unethical business activities. Journal of Business Ethics, 46(1), 85-97. https://doi.org/10.1023/A:102476751 1458

Gupta, M., Kumar, V., \& Singh, M. (2014). Creating satisfied employees through workplace spirituality: a study of the private insurance sector in Punjab (India). Journal of Business Ethics, 
122(1), 79-88.

https://doi.org/10.1007/s10551-0131756-5

Hackman, J. R., \& Oldham, G. R. (1975). Development of the job diagnostic survey. Journal of Applied Psychology, 60(2), 159-170.

https:// doi.org/10.1037/h0076546

Hansen, M., \& Keltner, D. (2012). Finding meaning at work, even when your job is dull. Retrieved from https://hbr.org/2012/12/findingmeaning-at-work-even-w

Harrington, W., Marschke, E., \& Preziosi, R. (n.d.). Support a relationship between organizational commitment and spirituality in the workplace. Journal Spirituality Workplace-Notepad.

Hassan, M., Bin Nadeem, A., \& Akhter, A. (2016). Impact of workplace spirituality on job satisfaction: Mediating effect of trust. Cogent Business \& Management, 3(1). https:// doi.org/10.1080/23311975.201 6.1189808

Karakas, F. (2010). Spirituality and performance in organizations: a literature review. Journal of Business Ethics, 94(1), 89-106.

Kinjerski, V. M., \& Skrypnek, B. J. (2004). Defining spirit at work: finding common ground. Journal of Organizational Change Management, 17(1), 26-42.

https://doi.org/10.1108/09534810410 511288

Luthans, F. (2011). Organizational behavior. New York: McGraw Hill.

Marschke, E., Preziosi, R., \& Harrington, W. (2009). Business executives and professionals identify relationship between spirituality at work and job satisfaction. Journal of Business $\mathcal{E}$ Economics Research.

Miller, D. W., \& Ewest, T. (2013). The present state of workplace spirituality: A literature leview considering context, theory, and measurement/assessment. Journal of Religious E Theological Information, 12(1-2), 29-54.

https:// doi.org/10.1080/10477845.201 3.800776

Mitroff, I. I., \& Denton, E. A. (n.d.). Spirituality in the workplace.

Retrieved February 20, 2017, from http://www.freebizplan.org/busines s_strategies/soft_skills/spirituality.ht $\mathrm{m}$

Mojoyinola, J. K. (2010). Helping patient to overcome suffering: the roles of spirituality in health, illness and treatment. International Journal of Literacy Education, 7(1).

Neck, C. P., \& Milliman, J. F. (1994). Thought self-leadership. Journal of Managerial Psychology, 9(6), 9-16. https:// doi.org/10.1108/02683949410 070151

Parmar, D. N. (2012). The review of job satisfaction. International Multidisciplinary E - Journal, I(IX), 1319.

Petchsawang, P., \& Duchon, D. (2012). Workplace spirituality, meditation, and work performance. Journal of Management, Spirituality \& Religion, 9(2), 189-208. https:/ / doi.org/10.1080/14766086.201 2.688623

Robbins, S. (2013). Organizational behavior, concept, controversies, applications. New Jersey: Prentice-Hall International, Inc.,Uppe Saddle River.

Sanders, J. E., Hopkins, W. E., \& Geroy, G. D. (2005). A causal assessment of the spirituality-leadership-commitment relationship. Journal of Management, Spirituality \& Religion, 2(1), 39-66. https:// doi.org/10.1080/14766080509 518566

Wexley, K. N., \& Yukl, G. A. (1988). Organizational behavior and personnel psychology. Boston: Richard D. Irwin, Inc. 